\title{
sciendo
}

\section{THE IMPACT OF LEGISLATIVE CHANGES ON THE NUMBER OF CALLS TO THE ROMANIAN COVID 19 TELVERDE HELPLINE}

\author{
MIHAI BUZATU ${ }^{1}$, GEORGETA DINCULESCU ${ }^{2}$, FLORENTINA LIGIA FURTUNESCU ${ }^{3}$, \\ DANA GALIETA MINC $\breve{A}^{4}$ \\ 1,2,3,4 "Carol Davila” University of Medicine and Pharmacy, Bucharest
}

\begin{abstract}
Keywords: Covid 19, Abstract: On 24 ${ }^{\text {th }}$ of February 2020, the Ministry of Health in Romania announced the telverde, green line, operationalization of the Green Line, known as Telverde, within the National Institute of Public emergency, military Health, in order to provide citizens with information related to the prevention of Sars-Cov-2 infection. ordinances The number of registered calls increased considerably at the time of the declaration of the pandemic, the beginning and the cessation of the state of emergency and during the issuance of military ordinances. Different key periods were studied and compared so that we could determine if the major administrative and legislative events have influenced the number of registered calls. Our findings sustained the supposition that the major events that took place during this period have indeed influenced the number of telephone calls made to TelVerde helpline.
\end{abstract}

\section{INTRODUCTION}

After the first confirmed case of coronavirus in Romania, the authorities put into operation a free telephone line, telverde, aimed to inform citizens about the infection with the Sars-cov-2 virus.(1,2)

The program began to operate within the National Institute of Public Health (NIPH) with employees of the institution as phone operators. In a short time, due to the high demand, the Green Line (TelVerde) project increased the number of telephone stations, thus needing more operators, including resident doctors and personnel from the Ministry of Defense.(1)

In addition to the fact that TelVerde has proven to be the most effective platform for informing citizens about the new coronavirus, it has also become an environment conducive to the development of the professional skills of the medical staff involved.(1,2)

Both the number of calls made to the TelVerde helpline and the type of questions asked varied from one day to another.

The citizens, calling either from Romania of from abroad, often wanted to find out new information on the status of countries at epidemiological risk for travel purposes, isolation or quarantine measures that were to be taken for people who were to enter the country, as well as basic information about the new virus, symptoms infection prevention methods.(1,2)

\section{AIM}

The aim of this six-month analysis is to identify whether the number of registered TelVerde calls was influenced by major administrative events dating from the $26^{\text {th }}$ of February 2020 (first reported case) to the end of the State of Emergency, the beginning of the State of Alert and until the $29^{\text {th }}$ of August 2020 .

\section{MATERIALS AND METHODS}

To comprehend the impact, we studied the main sources of information such as the official daily newsletters issued by the Ministry of Health (MH), the public data reports from the Ministry of Internal Affairs (MIA) as well as the press release statements of the Strategic Communication Group from within MIA and other national databases in order to acquire the essential data.

First, we identified and then we analysed several parameters as followed:

a. The number of Covid-19 Green Line calls that were made before, during the enforcement and after the cessation of the State of Emergency. $(3,4)$

b. The number of calls that were made after the World Health Organization (WHO) declared the Covid-19 pandemic. $(3,4)$

c. The number of calls made on the day of the announcement of each military ordinance and after the provisions came into force. d. The comparison between a two-month period consisting of the State of Emergency between the $16^{\text {th }}$ of March till the $15^{\text {th }}$ of May and another two-months period from the State of Alert from the $16^{\text {th }}$ of May till the $15^{\text {th }}$ of July. $(3,4)$

e. The number of calls made after the cessation of the State of Emergency and the beginning of the State of Alert followed by Government decision issues. $(3,4)$

For the analysis of the number of calls that were made before, during and after the State of Emergency, we summed up all the calls from each period and calculated the respective percentages. Then we compared the three obtained values, pointing out the effect of the enforcement of the state of emergency over the number of calls.

After that we studied the period between the implementation of TelVerde up until the enforcement of the State of Emergency, underlining the effect of WHO declaring the Covid-19 pandemic had on the number of calls that were

${ }^{1}$ Corresponding author Mihai Buzatu, Str. Leonte Anastasievici Nr. 1-3, București, România, E-mail: mihai.buzatu@drd.umfcd.ro, Phone: +40731 458438

Article received on 15.02.2020 and accepted for publication on 02.03.2021 


\section{PUBLIC HEALTH AND MANAGEMENT}

registered in that brief period of time.(5)

The overall evolution was taken into consideration in order to point out the trend line of the TelVerde calls during the whole studied period, from the $28^{\text {th }}$ of February till the $29^{\text {th }}$ of August.

The next parameter analysis consisted in evaluating the effects of the military ordinances on the number of calls from the days of issuance and the days following their entry into force, during the whole period of the State of Emergency between the 16th of March and the $15^{\text {th }}$ of May 2020.(2)

The last parameter was chosen to show the effect of the Government Decisions over the number of calls made in that period, between the $16^{\text {th }}$ of May till the $29^{\text {th }}$ of August, during the State of Alert. $(4,9)$

\section{RESULTS}

Our analysis over this six-month period, from the $26^{\text {th }}$ of February to the $29^{\text {th }}$ of August, has revealed that the enforcement of the State of Emergency increased the number of phone calls to the TelVerde line by $44 \%$, thus reaching a value of $56 \%$ (191.081 calls) in comparison with the number of calls from the Pre-State of Emergency period which represented 12\% (41.129 calls). Its cessation also influenced the number of TelVerde calls, reducing the number of calls by $24 \%$ and reaching a value of $32 \%$ (111.776 calls). $(3,4)$

Furthermore, before the World Health Organization declared the pandemic, the mean number of calls was around 1450 calls per day, whereas after the pandemic was declared, the mean number of calls per day spiked at 6268 (figure no. 2). $(3,4,5)$

Figure no. 1. The mean number of TelVerde calls before and after the World Health Organization declared the Covid-19 pandemic

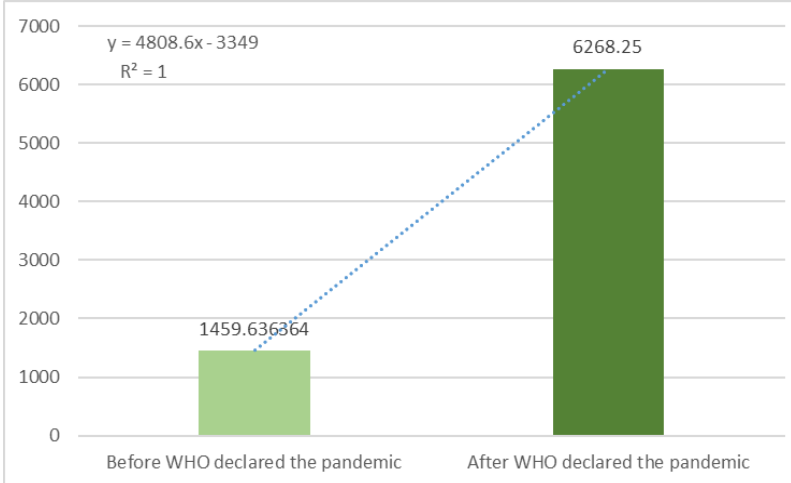

Each military ordinance (MO) came with a set of stric provisions and restrictions and the most impactful were the first $\mathrm{MO}$, that announced the lockdown, restrictions regarding public and private events, hospitality industry activity, public and cargo transports and flights (green) and the third MO (purple) that brought changes regarding the restrictions of circulation of citizens in public space that required an affidavit which was previously stated in the second MO (yellow). $(6,7,8,9)$

The number of calls registered on the days of announcement was always higher than the previous days, except for the case of MO 1 (5517 calls) that came right after the pandemic declaration period $\left(5616\right.$ calls on the $15^{\text {th }}$ of March).(2,3,6)

An increase of phone calls was also observed in the following days right after the provisions of each ordinance came into force (figure no. 3). The number of calls registered after the enforcement MO 1, were 6187 calls on the $17^{\text {th }}$ and 7885 on the $18^{\text {th }}$ of March. After the MO 3 enforcement on the $24^{\text {th }}$ of March (8171 TelVerde calls), there were two days of spiking values of
9359 calls on the $25^{\text {th }}$ and 10024 calls on the $26^{\text {th }} \cdot(3,4,6,8,9)$

Figure no. 2. The spiking of TelVerde calls on the days of MO announcements and following the enforcement of their provisions

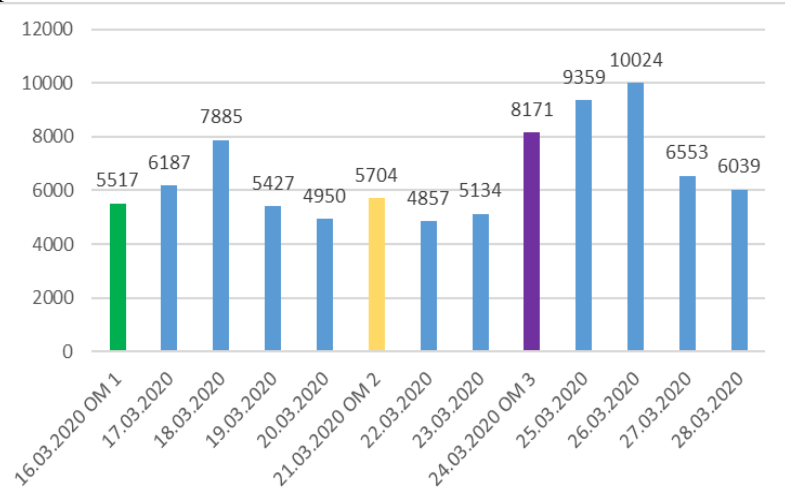

The rest of the military ordinances continued to influence the number of TelVerde calls as followed in table no. 1. $(3,4)$

Table no. 1. Number of TelVerde calls made on the days of Announcement of Military Ordinances no. 4 to 12 and of Empowerment of their provisions

\begin{tabular}{|c|c|c|}
\hline $\begin{array}{c}\text { Military } \\
\text { Ordinance No. }\end{array}$ & $\begin{array}{c}\text { No. of calls on } \\
\text { Announcement }\end{array}$ & $\begin{array}{c}\text { No. of calls on } \\
\text { Empoverement day }\end{array}$ \\
\hline $\mathbf{4}$ & 4118 & 3912 \\
\hline $\mathbf{5}$ & 3912 & 6393 \\
\hline $\mathbf{6}$ & 3912 & 6393 \\
\hline $\mathbf{7}$ & 4164 & 3300 \\
\hline $\mathbf{8}$ & 2109 & 2183 \\
\hline $\mathbf{9}$ & 1917 & 1982 \\
\hline $\mathbf{1 0}$ & 1197 & 2282 \\
\hline $\mathbf{1 1}$ & 815 & 1905 \\
\hline $\mathbf{1 2}$ & 1794 & 1932 \\
\hline
\end{tabular}

By comparing the two periods, one from the State of Emergency and one from the State of alert, both consisting of a two-month interval we discovered that the number of calls that were registered during the $16^{\text {th }}$ of March and the $15^{\text {th }}$ of May interval was considerably higher than the number registered to the second period between the $16^{\text {th }}$ of May and the $15^{\text {th }}$ of June (figure no. 3).(3,4)

Figure no. 3. Comparison between the number of registered calls in State of Emergency and State of Alert two-month intervals

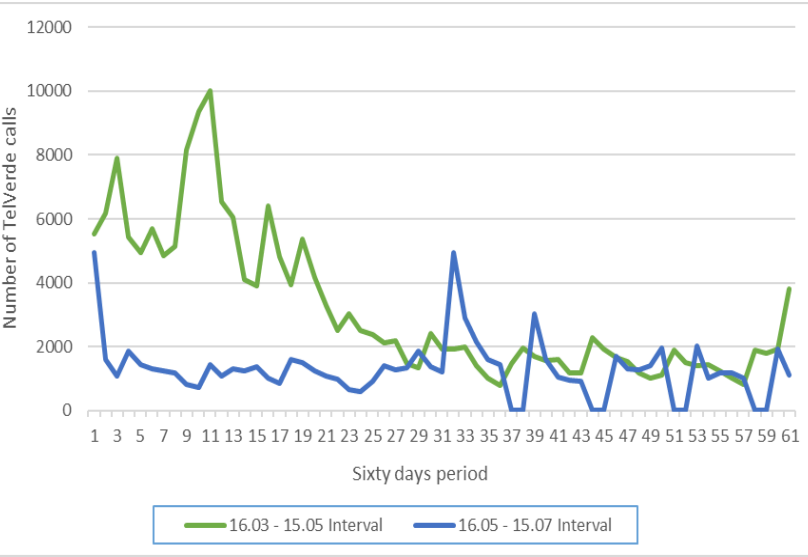




\section{PUBLIC HEALTH AND MANAGEMENT}

As previously discovered, during the State of Alert, the number of registered TelVerde calls followed a downward trajectory, with two exceptions that generated spikes in the registered phone calls.

The first one was right at the beginning, on the $15^{\text {th }}$ and $16^{\text {th }}$ of May, when the Government Decisions no. 24 and 394 (GD 24 and GD394) were announced and later enforced. These decisions brought various changes such as modifications to the affidavit and education access, citizen circulation outside the residential area or the reopening of dental offices and outpatient clinics for non-urgent cases.(9)

The second spike, and the most impressive, was caused by the Government Decision $476 / 2020$ on the $16^{\text {th }}$ and $17^{\text {th }}$ of June. This was the one that announced the reopening of certain hospitality industry sectors and fitness and spa treatment centres, kindergartens and afterschool programmes, changes to private event planning restrictions and the organization of exams in the educational sector.(9)

Figure no. 4. Registered TelVerde calls during the State of alert, descending trend and Government Decision related peaks

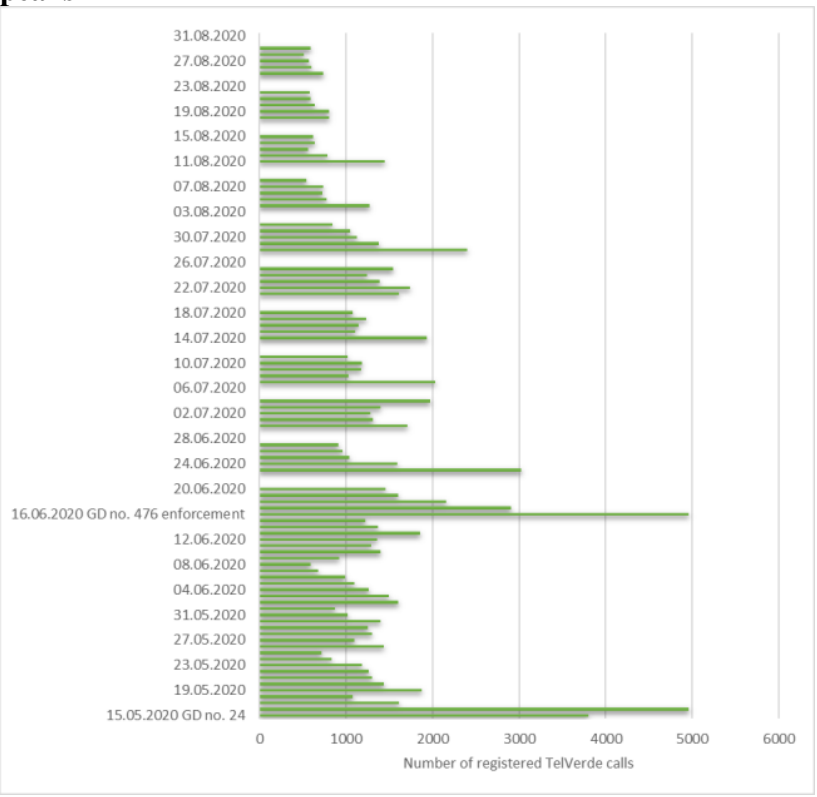

\section{DISCUSSIONS}

Our analysis revealed that the major legislative and administrative events that occurred during this period had indeed influenced the number of calls that the citizens of Romania have made to TelVerde helpline. Even though the State of Alert came with its own set of changes, those were relaxation measures that led to less incoming calls.

Moreover, the study indicates that $68 \%$ of the calls (232.210) were received from the beginning of the pandemic until the end of the State of Emergency and only 32\% (111.776) for the rest of the study period. $(3,4)$

\section{CONCLUSIONS}

The provisions and restrictions that came with the Military Ordinances have generated a series of questions spanning from the medical aspects of the pandemic, to the legislation alterations that were changing frequently.

It was most obvious that people felt the need to access this source of information at a greater level during the State of Emergency period since that was the time when the legislative and administrative modifications had the most impacting consequences on their everyday lives.

\begin{tabular}{llll}
\multicolumn{5}{c}{ REFERENCES } \\
1. National Institute of Public Health
\end{tabular}
https://insp.gov.ro/dj/comunicate/Informare\%20cu\%20priv ire\%201a\%20activitatea\%20TELVERDE.pdf Accessed at 20.05.2020.

2. Ministry of Internal Affairs https://www.mai.gov.ro/buletin-informativ-27-februarieora-10-00/ Accessed at 10.03.2020.

3. Ministry of Health. Newsletter. Press releases. http://www.ms.ro/comunicate/ 65-154 Accessed at 30.08 .2020

4. Ministry of Internal Affairs, Strategic Communication Group. Press releases https://www.mai.gov.ro/category/comunicate-de-presa/ Accessed at 30.08.2020.

5. World Health Organization. Director General's opening remarks at media briefing. https://www.who.int/directorgeneral/speeches/detail/who-director-general-s-openingremarks-at-the-media-briefing-on-covid-19---11-march2020 Accessed at 13.03.2020.

6. Ministry of Internal Affairs. Military Ordinance 1. 16.03.2020 https://www.mai.gov.ro/wpcontent/uploads/2020/03/Ordonan\%C8\%9Bamilitar\%C4\%83-nr.-1-2020-m\%C4\%83suri-de-primaurgen\%C8\%9B\%C4\%83-Decret.pdf Accessed 19.03.2020.

7. Ministry of Internal Affairs. Military Ordinance 2. 21.03.2020 https://www.mai.gov.ro/wpcontent/uploads/2020/03/Ordonanta-militar\%C4\%83-nr.-22020-m\%C4\%83suri-prevenire-COVID-19-1-1.pdf Accessed at 22.03.2020.

8. Ministry of Internal Affairs. Military Ordinance 3 . 27.03.2020 https://www.mai.gov.ro/ordonanta-militara-nr3-din-24-03-2020-privind-masuri-de-prevenire-araspandirii-covid-19/ Accessed at 29.05.2020.

9. Government of Romania. Measures. GD24, GD24 Annex, Accessed at 29.05.2020.

10. Government $394 / 18.05 .2020$ http://legislatie.just.ro/Public/DetaliiDocument/225876 Accessed at 22.05.2020.

11. Government Decision 476/2020 16.06.2020-17.06.2020 http://legislatie.just.ro/Public/DetaliiDocument/226824 Accessed at 25.06.2020. 